\title{
最近の歯学
}

\section{5. 歯科放射線}

\section{ヒトのロ腔癌細胞集団の動態について \\ 東京医科歯科大学歯科放射線学教室 佐久間 順 子 中 村 正}

口腔癌は直接目で文るといらことで，放射線治療の 経過をとら光，そこから物を考光たりするのに好都合で ある。例えば扁平上皮癌というように, 病理組織学的診 断名が同じであっても, 治療経過が全く違う事例にあう ことはしばしばである。治療開始後“みるみる”といっ ていい汪ど癌が小さくなる症例もあれば，逆になかなか 反応をを示さない症例もある。

病理組織学的な診断要素とは別な要素が, 癌の細胞集 団に内含されていて, 放射線に対する態度を, 变えさせ ているのではないかといら発想をした。

細胞は, DNA 合成準備期 ( $G_{1}$ 期), DNA 合成期 ( $\mathrm{S}$ 期), 分裂準備期 $\left(G_{2}\right.$ 期 $)$, 分裂期 $(M$ 期 $)$ を経て次の世代に移 る。放射線の生物学的作用は, 分裂を介して増幅される ので, この生涯の長さが, 放射線と細胞集団との相互作 用を修飾することになる。細胞集団で潅察時, すべて の細胞は同じ期にはいない。

組織学実習で, 分裂中の細胞を容易にみつけられなか った思い出はホ口苦い。当然の事ながら, 集団の中で, 観察時に上記 4 つの期に属する細胞の数は, 細胞がそれ ぞれの期㵒す時間に比例する。また，これらの時問の 和は細胞の一生涯であって, 全体の増え方を規定する。

大きくなり方が “ゆっくり”である癌と, “あっとい う間”に大きくなる癌という, 臨床経験の説明に細胞の 一生涯, ひいては細胞集団の細炮数の増加という要素を 導入してみた。逆にいえば，放射線の照射によって“み るみる”小さくなる例と、“なかなか小さくならない” 例との説明のための要素である。他に, 生きていながら 前記の経過をたどらず, 分裂に参加しない細胞があり, $\mathrm{G}_{0}$ 期にいると呼ばれる。 $\mathrm{G}_{0}$ 期の細胞は, 放射線の生物 学的作用に対して抵抗を示して, 癌の放射線治療の場 合，再発の原因とされる。
細胞の一生涯の 記録には, 顕微映画法が 合理的であ る。が, 実験室を離れて, ヒトの癌を相手取り, 生体外 二重標識法なる方法を用い, 細胞の生涯を計った。

ヒトの口腔癌の細片を生体外で, DNA 合成中の細胞 に取り込まれるチミジンに ${ }^{3} \mathrm{H} ，{ }^{14} \mathrm{C}$ という放射性同位元 素で目印をつけた化合物を用い，標識した。DNA 合成 中の細胞の数, DNA 合成を終わって分裂に入った細胞 の数などから, 癌細胞集団の動きを探った。

方法の詳細は, The Bulletin of Tokyo Medical and Dental University, Vol, 27. No. 1, pp. 43 54, March, 1980 誌上で発表した。

結果は, 表 1 亿あるように, 同じ病理組織学的診断名 の下にある 細胞集団でも全く異なった動態を示してい た。

分裂に関与しない細胞のしめる割合，全体として短い 時間で “大きくなる癌”，放射線の作用を強く表現する 癌等, 同一病理組織学的診断名の下にあっても“動き” は違っていたといえた。

表 $13 \mathrm{a}$ と3bは同 1 症例で異なった場所か ら採取した標本についての結果

\begin{tabular}{c|c}
\hline 症例番号 & 細胞生涯の長さ(時間) \\
\hline 1 & 47.0 \\
2 & 54.7 \\
$3 \mathrm{a}$ & 21.7 \\
$3 \mathrm{~b}$ & 24.3 \\
4 & 28.5 \\
5 & 27.7 \\
6 & 42.1 \\
7 & 32.3 \\
8 & 38.1
\end{tabular}

